\title{
Trace Elements and Oxygen Isotopes in Garnets from Diamondiferous Xenoliths, Nurbinskaya pipe, Yakutia: Implications for Diamond Genesis
}

\author{
Z. V. Spetsius ${ }^{1}$, W.L. Griffin ${ }^{2}$, L. A. Taylor ${ }^{3}$, S.Y. O'Reilly ${ }^{2}$, S.I. Mityukhin ${ }^{4}$, J.W.Valley ${ }^{5}$ \\ and M. Spicuzza ${ }^{5}$
}

\author{
${ }^{I}$ YaNIGP CNIGRI, ALROSA Co. Ltd., Mirny, Yakutia,Russia, spetsius@cnigri.alrosa-mir.ru \\ ${ }^{2}$ GEMOC ARC National Key Centre, Macquarie University, NSW 2109, Australia; \\ ${ }^{3}$ Planetary Geosciences Institute, Dept. of Geological Sciences, Univ. of Tennessee, USA; \\ ${ }^{4}$ ALROSA Co. Ltd., Mirny, Yakutia, Russia; \\ ${ }^{5}$ Dept.of Geosciences and Geophysics, Univ. of Wisconsin, Madison, WI 53706 USA.
}

A large collection (160) of xenoliths and garnetmegacrysts with diamonds from the Nyurbinskaya pipe shows several extreme features: exceptionally high diamond grade in individual samples, a predominance of diamonds with eclogitic paragenesis, evidence for metasomatic diamond growth and anomalous $\delta^{18} \mathrm{O}$ values of garnets in diamonddiferous xenoliths (Fig. 1). The mineral chemistry, isotopic compositions and diamond characteristics of this suite provide new insights into the origin and modification of eclogites, the composition of the lithospheric mantle under this kimberlite field and the metasomatic origin of diamonds.

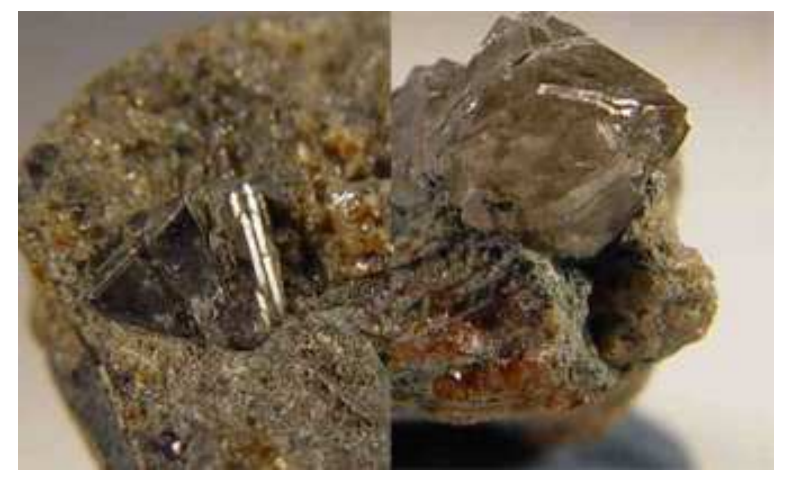

Fig. 1. Diamonddiferous xenoliths from Nyurbinskaya pipe. Size of diamonds is 4 and $5 \mathrm{~mm}$.

\section{Methodology}

Major element compositions of garnets in the xenoliths were determined with a Superprobe JXA-8800R electron microprobe at the ALROSA Co Ltd. (Mirny,
Yakutia). Natural minerals and synthetic were used as standards. Analytical conditions included an accelerating voltage of $15 \mathrm{keV}$, a beam current of 20 $\mathrm{nA}$, beam size of $5 \mu \mathrm{m}$, and 20 seconds counting time for all elements. All analyses underwent a full ZAF correction.

The trace elements (TRE) have been measured in garnets of eclogites and other xenoliths by laser Ablation ICP-MS (LAM) at the Macquarie University in Sydney, with NIST 610 glass as external standard and $\mathrm{Ca}$ as internal standard; pit diameters were 40 $50 \mathrm{~mm}$. Rare earth elements (REE) and other trace elements were analyzed by LAM-ICPMS in garnets of 80 mafic and ultramafic xenoliths.

Fresh garnet grains for oxygen determinations were selected from 121 garnets. Pure separates were obtained using heavy liquids, magnetic separation, but mostly by careful hand picking. The oxygen-isotope analyses were performed on garnet mineral separates, approximately 1-2 mg per run, using a $32 \mathrm{~W} \mathrm{CO}_{2}$ laser, $\mathrm{BrF}_{5}$, and a dual-inlet Finnigan MAT 251 mass spectrometer. Replicate analyses were performed on many samples, particularly those that had oxygen values outside that of mantle. The procedure for the laser technique is discussed in Valley et al. (1998). The long-term precision for analyses of UWG-2 is $\pm 0.07 \%$ o (1SD), and daily precision is typically $\pm 0.05 \%$. 


\section{Results}

Factor analysis of garnet major-element chemistry identifies 8 paragenetic groups of xenoliths and megacrysts with diamonds, corresponding to different types of mantle xenolith (Spetsius et al., 2006). Of the entire suite of samples in this study, $>60 \%$ are eclogitic and websteritic, whereas dunite-harzburgite xenoliths constitute $<10 \%$ of the entire population of diamondiferous xenoliths. The large range in garnet compositions of the investigated xenoliths is apparent in the ternary plot in Fig. 2. It is obvious that most diamondiferous samples from the Nyurbinskaya pipe occupy fields of groups $\mathrm{B}$ and $\mathrm{C}$ eclogites. Most garnets are homogeneous in terms of major- and traceelement contents but about $20 \%$ of the samples have slightly zoned garnets.

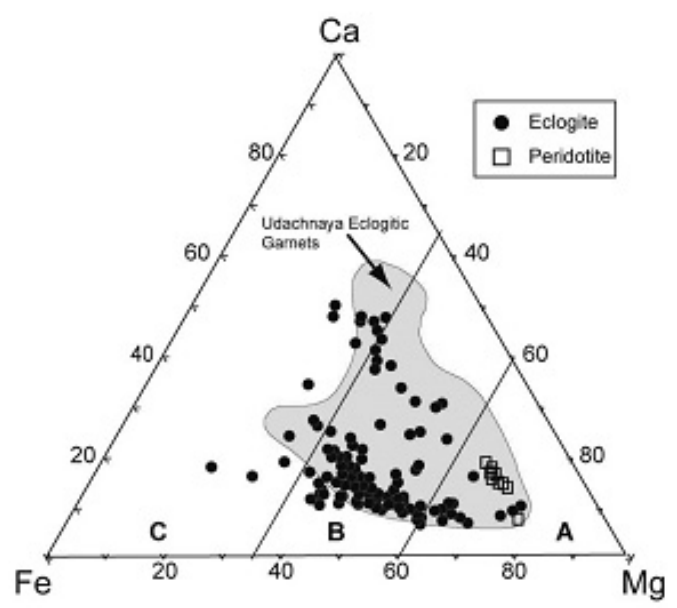

Fig. 2. Garnet compositions in xenoliths from the Nyurbinskaya pipe. The envelope outlines the compositional field of diamonddiferous xenoliths from the Udachnaya pipe, after Spetsius (2004).

\section{Trace elements distribution in garnets of xenoliths}

Garnets from ultramafic xenoliths define two groups, one with sinusoidal $\mathrm{REE}_{\mathrm{N}}$ (chondrite normalised) patterns (10 harzburgites, two lherzolites) and one with flat $\mathrm{MREE}_{\mathrm{N}}$ (lherzolites, some websterites). Most eclogitic garnets have LREE-depleted patterns $\left(\mathrm{Ce}_{\mathrm{N}}\right.$ as low as 0.1), and no Eu anomalies. HREE are variably enriched; most $\mathrm{Lu}_{\mathrm{N}}$ varies from 20-50 (Fig. 3). Most websteritic garnets show REE patterns similar to this but they are typically enriched in LREE with $\mathrm{Ce}_{\mathrm{N}}(0.2-$ $0.5)$. Another group of garnets $(n=9)$ from eclogites and websterites has small negative Eu anomalies. Garnets with nearly flat HREE and small positive Eu anomalies are common in coesite eclogites and those containing kyanite and/or corundum. Garnets of corundumbearing eclogites commonly have positive slopes within the $\mathrm{LREE}_{\mathrm{N}}$, peaking at Sm and then slowly decreasing to about chondritic abundance for $\mathrm{Lu}$. LAM-ICPMS analyses show how different populations within an eclogite xenolith series can document the heterogeneity of the lithospheric mantle.

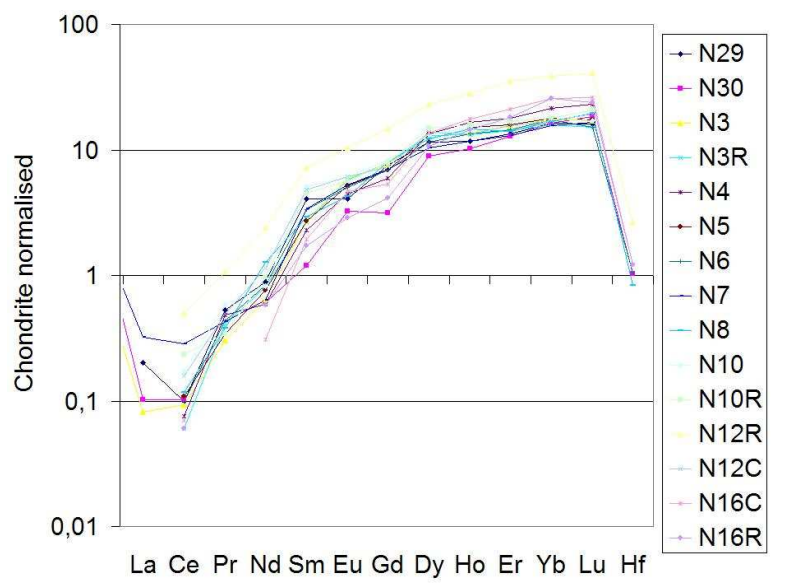

Fig. 3. REE distribution in eclogitic garnets.

\section{Oxygen isotope garnets compositions}

Oxygen isotope compositions of garnets display a large range of values, with most higher than the accepted mantle range of $5.3 \pm 0.3 \%$ (Fig. 4). In fact, for the eclogite xenoliths, the garnet values for a steep-sided bell-shaped curve about $1.2 \%$ wide with a mode at $\sim 6.6 \%$. This abundance of high $\delta^{18} \mathrm{O}$ values in garnets from xenoliths of any single kimberlite pipe appears to be unique, and suggests intense modification of the lithospheric mantle beneath this kimberlite field.

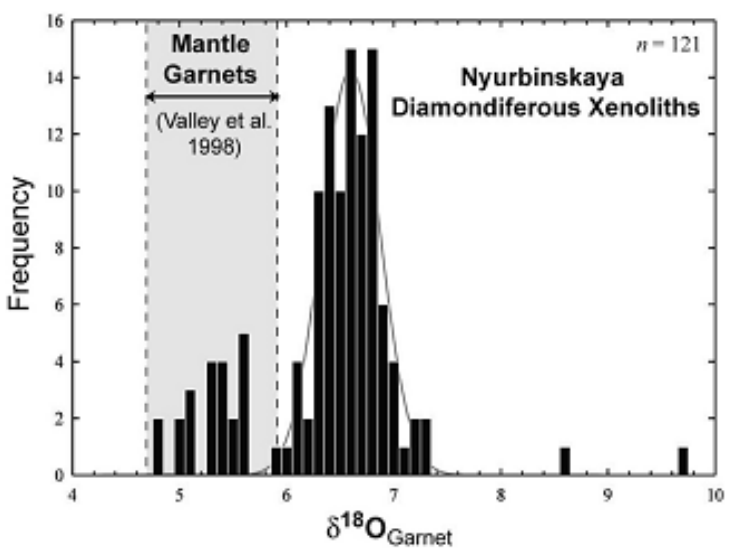

Fig. 4. Oxygen-isotope ratios of garnets in mantle xenoliths from the Nyurbinskaya pipe. 


\section{Metasomatic growth of diamonds}

The unusual range of high $\delta^{18} \mathrm{O}$ values is accompanied by evidence for strong late-stage metasomatism. We suggest that mantle metasomatic fluids may also possess crustal isotopic signatures, as a result of ancient subduction. The possible correlation of high oxygen-isotope values in many Nyurbinskaya xenolithic garnets with chemical zonations of garnets and strong metasomatic alteration might indicate that the xenoliths experienced fractionation through metasomatic influence. There is ample evidence that of the wide distribution of chemically zoned garnet in the present suite of investigated xenoliths, as well as the extensive development of phlogopite and other metasomatic minerals (Fig. 6).

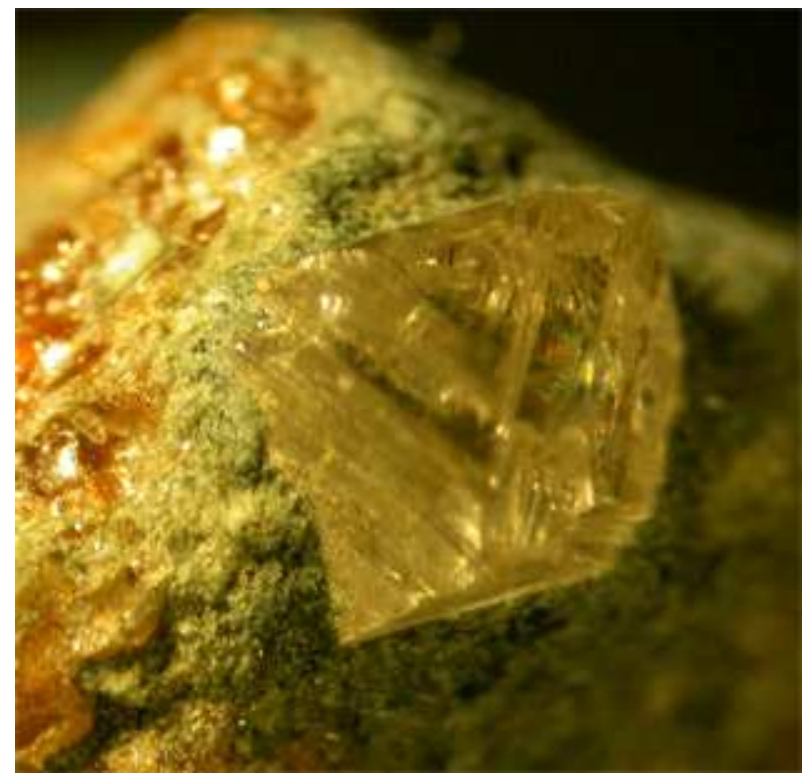

Fig. 6. Octahedron $(4 \mathrm{~mm})$ in the Nyurbinskaya xenolith surrounded by phlogopite rim that is replaced by chlorite.

In addition, many of the xenoliths possess textures of deformation and catalysis, as well as veins of partial melt products, similar to those described from the Udachnaya pipe (Spetsius and Taylor, 2002). Based upon many of the facts and observation discussed (Spetsius, 1999; Spetsius and Taylor, 2002), it is possible to speculate on the late-stage metasomatic diamond formation in some eclogites. Proof of this process can be seen in the distribution of diamond crystals within the products of kelyphite rims around garnet, as well as along general zones of partial melting. Such relations of diamonds in space have been found in eclogite xenoliths from the Udachnaya, and other Yakutian pipes. Close indications of the metasomatic origin of diamonds are seen in some xenoliths from the Nyurbinskaya pipe (Fig. 7).

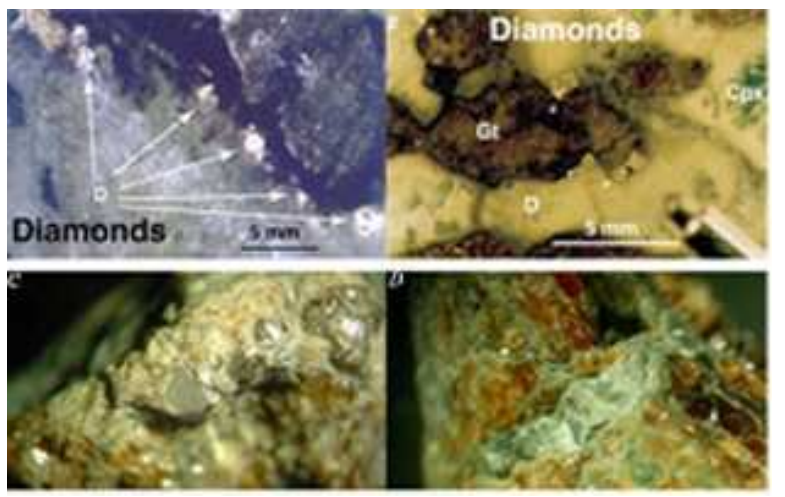

Fig. 7. Examples of metasomatic growth of diamonds. a) \& b) Diamonds in kelyphite rims and partial melt (both are eclogitic xenoliths from the Udachnaya pipe); c) Linear distribution of 5 diamonds in corundum eclogite (Nyurbinskaya pipe, size of crystals 3-4 mm); d) Eclogitic xenolith cut by thr diamond vein (Nyurbinskaya pipe).

\section{References}

Spetsius, Z.V., 1999. Two generation of diamonds in the eclogite xenoliths. In: Gurney, J.J., Gurney, J.L., Pascoe, M.D. \& Richardson, S.H. (eds). Proceedings of 7th IKC, 2. Cape Town: Red Roof Design, 823-828.

Spetsius, Z.V., 2004. Petrology of highly aluminous xenoliths from kimberlites of Yakutia. Lithos, 77, 525-538.

Spetsius, Z.V., Ivanov, A.S., Mitukhin, S.I., 2006. Associations with the diamond in kimberlites of the Nurbinskaya pipe, (Nakynsky field, Yakutia). Dokl. Akad. Nauk, 408, № 6, 810 -814 (in Russian).

Spetsius, Z.V., Taylor, L.A., 2002. Partial melting in mantle eclogite xenoliths: evidence from Yakutian kimberlites. Intern. Geol. Rew., 11, 983-987.

Valley, J.W., Graham, C.M., Harte, B., Eiler, J.M., and Kinney, P.D., 1998. Ion microprobe analysis of oxygen, carbon, and hydrogen isotope ratios. SEG Rev. Econ. Geol., 7, 73-98. 
